Prace Filologiczne. Literaturoznawstwo 11(14) 2021

ISSN 2084-6045

e-ISSN 2658-2503

Creative Commons: Uznanie autorstwa 3.0 PL (CC BY)

DOI: $10.32798 /$ pflit.541

\title{
WERS NA POGRANICZACH WERSOLOGII
}

\author{
Grey Areas of Versology
}

\author{
WOJCIECH PIETRAS \\ Uniwersytet Warszawski, Polska \\ E-mail:w_pietras@poczta.fm \\ https://orcid.org/0000-0002-3079-5137
}

\begin{abstract}
The theories of free verse that Polish versologists have developed so far presuppose that a verse in a sense of an individual line in a poem is a fundamental and a tangible composition unit of a versed text, which means the reader must be able to identify when the verse begins and finishes. Yet, for the past few decades a clear tendency has been noticed in Polish poetry that blurs the clarity of versification or, what is worse, disposes of prosodic, metrical and graphic mechanisms of poetry delimitation that are well-grounded in literary tradition. It seems that the graphic layout of a poem is gaining in importance, yet many poems that follow this tendency do not comply with the criteria of the theory of free verse as an example of a graphic text. As a consequence, there are pieces of contemporary Polish poetry whose status is ambiguous as they belong neither to the category of free verse nor the prose and therefore, bearing in mind the current presupposition on verse, the free verse theories advocated by Polish scholars seem irrelevant in this particular case. This article aims at identifying the challenges these unclassifiable poems confront versologists with. Also, it attempts to point out semantic possibilities available exclusively in this grey area of versology.
\end{abstract}

Keywords: borderland between free verse and prose, free verse theory, graphic text, verse delimitation, typographic prosody

\section{Streszczenie}

Dotychczasowe teorie wiersza wolnego wypracowane przez polskich wersologów zakładają, że wers jest podstawową i łatwo uchwytną jednostką kompozycyjną tekstu wierszowanego. Tymczasem w poezji polskiej ostatnich dziesięcioleci wyraźnie zaznacza się tendencja do zakłócania wyrazistości podziału na wersy, a nawet do zupełnej rezygnacji z ugruntowanych w tradycji literackiej mechanizmów delimitacji wierszowej (prozodyjnych, rytmicznych czy graficznych). Z drugiej strony, coraz większe znaczenie zdaje się zyskiwać graficzne ukształtowanie utworów poetyckich, spośród których wiele nie mieści się jednak w teorii tekstu graficznego. 
W konsekwencji powstają utwory o niejasnym statusie, sytuujące się na pograniczu wiersza wolnego i prozy. Z uwagi na wspomniane założenie teorie wiersza wolnego zaproponowane przez polskich badaczy wydają się nieprzystosowane do opisu mechanizmów kompozycyjnych w tego typu tekstach. Niniejszy artykuł jest próbą rozpoznania wyzwań, które przed wersologią stawiają utwory niedające się w sposób bezdyskusyjny zaklasyfikować ani do wiersza wolnego, ani do prozy. Jednocześnie jest to próba wskazania semantycznych możliwości dostępnych wyłącznie na tak rozumianym obszarze pogranicznym.

Słowa kluczowe: pogranicze wiersza wolnego i prozy, teoria wiersza wolnego, tekst graficzny, delimitacja wierszowa, prozodia zapisu

Jak zauważył Artur Grabowski, odpowiedź na pytanie, czym jest wers pojęcie kluczowe dla wiersza i wersologii - nie jest wcale łatwa ${ }^{1}$. Współcześnie wielu autorów dąży do zatarcia wyrazistości podziału na wersy. Ich utwory częstokroć zawierają sugestię, że należy je uznawać za wiersze (wolne), przy jednoczesnej rezygnacji z „tradycyjnych” czynników zapewniających wyrazistość wierszowego ukształtowania.

Sprawy nie ułatwiają dotychczasowe teorie wiersza wolnego, które skoncentrowały się na jego wyrazistych reprezentacjach (różnych dla różnych teorii) i z tego powodu wydają się nieprzystosowane do opisu zjawisk mniej typowych. Utwory poetyckie ciążące ku prozie są w ujęciach teoretycznych albo pomijane, albo ogólnikowo zaliczane do obszaru pogranicza. W konsekwencji trudno orzec, gdzie kończy się „typowy” wiersz wolny, a zaczyna „typowa” proza. Adam Kulawik ${ }^{2}$, Dorota Urbańska ${ }^{3}$ i Artur Grabowski ${ }^{4}$ zakładają pewną płynność granicy pomiędzy obydwoma kategoriami, nie proponują jednak żadnych narzędzi do opisu tekstów o zachwianej czytelności wierszowego ukształtowania. Na gruncie tych koncepcji pozostaje więc takie kompozycje albo jednoznacznie zaklasyfikować jako wiersz - i wtedy próbować analizować z wykorzystaniem obranej teorii (nastręcza to jednak wielu problemów), albo uznać za prozę i wykluczyć z badań wersologicznych. Tak też problem pogranicza podsumowała Maria Dłuska ${ }^{5}$, która spośród polskich teoretyków wiersza poświęciła mu bodaj najwięcej uwagi.

\footnotetext{
${ }^{1}$ A. Grabowski, Wiersz, forma i sens, Kraków 1999, s. 29.

${ }^{2}$ A. Kulawik, Wersologia. Studium wiersza, metru i kompozycji wersyfikacyjnej, Kraków 1999, s. 214.

${ }^{3}$ D. Urbańska, Wiersz wolny. Próba charakterystyki systemowej, Warszawa 1995, s. 10.

${ }^{4}$ Grabowski wskazuje, że zastosowanie wiersza musi być fortunne, inaczej tekst może nie zostać rozpoznany jako wiersz. Cf. idem, op. cit., s. 129-130 i 163.

${ }^{5}$ Cf. M. Dłuska, Między proza a wierszem, w: eadem, Prace wybrane, t. 3, Kraków 2001, s. 352-366, oraz eadem, Drugi szkic o pograniczu prozy $i$ wiersza, w: eadem, op. cit., s. 367-387. Spośród prac podejmujących pojedyncze zagadnienia związane z obszarem pogranicza wskazać można jeszcze: W. Borowy, Rytmika prozy Żeromskiego, w: idem, O Żeromskim. Rozprawy i szkice, wyd. 2, Warszawa 1964, a także M. Dłuska, Modernistyczny barok Żeromskiego. Studium prozy poetyckiej pisarza, w: eadem, op. cit., s. 297-351. Również Maria Renata Mayenowa
} 
Przyczynę obecnej sytuacji stanowić może problem nadrzędny: w wersologii nadal nie do końca rozwiązana pozostaje kwestia (rosnącego?) znaczenia wizualnej organizacji tekstów poetyckich. Grabowski poczynił co prawda ogólne spostrzeżenia, zgodnie z którymi w obręb wiersza włączać można rozmaite, nie tylko językowe znaki, myśl ta nie została jednak przez niego rozwinięta. Uszczegółowił ją Witold Sadowski w swojej teorii wiersza wolnego opartej właśnie na graficzności ${ }^{6}$, w koncepcji tej istnieją jednak pewne ograniczenia, związane przede wszystkim z kluczowym dla niej pojęciem linijki.

Niniejszy artykuł jest próbą rozpoznania wyzwań, jakie przed teoriami wersologicznymi coraz wyraźniej stawia poezja najnowsza. Do wyzwań tych należą: 1) osłabienie sygnałów delimitacji wierszowej i rozmycie granic wersu (co bywa ujmowane szerzej jako ciążenie wiersza wolnego ku prozie) oraz 2) ekspozycja graficznego (przestrzennego) wymiaru tekstu (czego przejawem lub konsekwencją może być właśnie owa słabsza wyrazistość delimitacyjna). Analizowany materiał stanowią w większości utwory opublikowane w XXI w., jednak niektóre z omawianych zjawisk występowały już od połowy poprzedniego stulecia (a ich początki wskazać by można jeszcze wcześniej - w twórczości awangardy przedwojennej). $\mathrm{Z}$ tego też względu poczynione tutaj rozpoznania dotyczą poezji polskiej ostatnich 70 lat (a więc w wyczerpującym opisie diachronicznym przedział ten wymagałby rozszerzenia). Zasadniczym teoretycznym punktem odniesienia w dalszych uszczegółowionych analizach będzie teoria wiersza wolnego jako tekstu graficznego, ponieważ prozodia zapisu ${ }^{7}$ odgrywa kluczową rolę w proponowanym tu ujęciu.

w Poetyce teoretycznej poświęciła nieco miejsca zrytmizowanej prozie jako formie o - podobnie jak wiersz - ekspresywnym ukształtowaniu prozodyjnym; badaczka przyjęła jednak istnienie wyraźnej opozycji pomiędzy wierszem a prozą, tak że zagadnienie pogranicza nie pojawia się w jej książce. Vide M. R. Mayenowa, Poetyka teoretyczna, wyd. 3, Wrocław et al. 2000, s. 358-419, w szczególności s. 368-379. W tejże pracy badaczka sygnalizuje także problematykę związaną $\mathrm{z}$ wizualnym aspektem wiersza wolnego, cf. ibidem, s. 401-406. Polscy badacze wiersza zwrócili ponadto uwagę na gatunek litanii jako sytuujący się gdzieś na pograniczu wiersza i prozy; w tym kontekście litanię przywołała najpierw M. Dłuska w Studiach z historii i teorii wersyfikacji polskiej, t. 2, Warszawa 1978, s. 190-197; następnie zagadnienie to w sposób systematyczny opracował - proponując jednocześnie pojęcie „wiersza litanijnego” - Witold Sadowski, vide idem, Litania i poezja, Warszawa 2011, s. 111-145 oraz idem, Europejski wiersz litanijny, Warszawa 2018, w szczególności s. 71-80.

${ }^{6}$ W. Sadowski, Wiersz wolny jako tekst graficzny, Kraków 2004.

${ }^{7}$ Punktem wyjścia będzie znaczenie tego pojęcia zaproponowane przez Sadowskiego w Wierszu wolnym jako tekście graficznym. Prozodia zapisu jest przez badacza rozumiana ,jako zjawisko nadania wartości znaczeniowych, stylistycznych, wersyfikacyjnych czy innych [...] elementom stosowanym przeważnie w procesie technicznej obróbki książki” (s. 216). W ujęciu Sadowskiego „na prozodię zapisu składa się przede wszystkim autonomiczna graficznie długość linijek oraz autonomiczna segmentacja na odcinki przestrzenne" (s. 241), którym towarzyszyć mogą inne zjawiska graficzne, cf. ibidem, s. 215-244. Zgodnie z założeniami niniejszego artykułu takie rozumienie prozodii zapisu nie sprawdza się w analizie pogranicza wiersza wolnego i prozy, dlatego dalej zostanie zaproponowana pewna modyfikacja znaczenia tego pojęcia. 


\section{Problem pogranicza wiersza wolnego i prozy}

Pełnia i uchwytna indywidualność to, zdaniem Grabowskiego, te cechy wersu, które każą postrzegać go jako szczególną jednostkę tekstu ${ }^{8}$. Zadaniem dla poety jest więc odpowiednie zabezpieczenie czytelności wierszowego podziału i wyeksponowanie wspomnianych cech. Pewien kłopot dla czytelnika i badacza pojawia się jednak, kiedy autor zdaje się to zadanie ignorować. Rodzi się wtedy pytanie, jak (i czy w ogóle) funkcjonuje podział wierszowy w utworach nawiązujących w jakiś sposób do graficznej segmentacji wiersza wolnego, a jednocześnie rezygnujących z konwencji przejrzystego i czytelnego wyodrębniania wersów? Szczegółowe teoretyczne opracowania wiersza wolnego nie dostarczają na to pytanie odpowiedzi, jako że zostały obmyślone przy założeniu, że wers zawsze występuje w funkcji podstawowej i klarownej jednostki wiersza.

Urbańska $^{9}$ oraz Kulawik ${ }^{10}$ definiują wers jako odcinek tekstu zakończony (i wyodrębniony) pauzą wersyfikacyjną, silniejszą od pauz składniowych i dzięki temu łatwo uchwytną. Pauza wersyfikacyjna nie zawsze jest jednak w stanie zagwarantować wyraźną odrębność wersu, ponieważ, po pierwsze, w seriach długich wersów o złożonej składni przestaje być „słyszalna”; po drugie, w niektórych sytuacjach jej pojawienie się na końcu wyodrębnionego graficznie wersu wydaje się niejako dziełem przypadku.

Również relacyjność wersowa czy akomodacja tekstowa, opisane w niedawno wydanej książce Krzysztofa Skibskiego ${ }^{11}$, wydają się mało przydatne do opisu mechanizmu delimitacji wierszowej w przypadku utworów o długich, rozbudowanych wersach. Nadwyżka semantyczna (czyli spotęgowany, dzięki podziałowi na wersy, potencjał znaczeniowy poszczególnych wyrazów i struktur składniowych) występuje ze wskazaną przez badacza intensywnością w utworach o wersach krótkich. Pomiędzy wszystkimi elementami wersów długich i całymi takimi wersami musiałaby jednak prowadzić do (niemal) zupełnego rozmycia przekazu, uniemożliwiając stworzenie spójnego projektu interpretacyjnego ${ }^{12}$.

Podobnie wcześniejsza, przywołana już, teoria Sadowskiego (w świetle której wiersz wolny to tekst zorganizowany w autonomiczne jednostki graficzne, czyli linijki) sprawdza się świetnie w odniesieniu do wierszy, gdzie owa autonomiczność jest niezaprzeczalna i dobrze widoczna. W zestawieniu z utworami mniej pod tym względem wyrazistymi jawi się jednak jako niewystarczająca.

\footnotetext{
${ }^{8}$ A. Grabowski, op. cit., s. $30-34$.

${ }^{9}$ D. Urbańska, op. cit., s. 14-16.

${ }^{10}$ A. Kulawik, op. cit., s. 55 et al.

${ }^{11}$ K. Skibski, Poezja jako iteratura, Poznań 2017.

${ }^{12}$ Cf. ibidem, s. 36-45.
} 
Przywołane teorie zdają się opierać na (i odnosić do) takiej twórczości poetyckiej, o której czytelnik już zawczasu wie, że należy ją rozpatrywać jako wierszowaną. Nie zawsze jednak klasyfikacja taka dokonuje się bez wątpliwości. Zdarza się też tak, że analiza z wykorzystaniem któregoś z teoretycznych wyróżników wiersza wolnego pozwala wprawdzie obronić istnienie delimitacji wierszowej w danym tekście, ale odbywa się to kosztem zubożenia semantyki utworu.

Poniższa próba przeglądu i usystematyzowania tych (niektórych) kłopotliwych dla wersologii zjawisk $\mathrm{w}$ polskiej poezji ostatniego siedemdziesięciolecia pomyślana została jako rozpoznanie do dalszych badań, które pozwoliłyby na usystematyzowany opis obszaru pogranicza wiersza wolnego i prozy. Jednocześnie przyjmuje się założenie, że utwory przedstawione tu jako pograniczne należy analizować właśnie jako takie, a nie $\mathrm{z}$ intencją potwierdzenia (lub zaprzeczenia) ich kompozycji wersowej przy użyciu któregoś z wersologicznych kryteriów.

\section{Serie długich wersów}

W omawianym tutaj okresie w poezji polskiej pojawiło się wiele utworów, w których uchwycenie wersu jako jednostki wyodrębnionej w sposób tradycyjny - dzięki prozodii (pauzie lub intonacji) wydaje się trudne, o ile w ogóle możliwe. Taka niejednoznaczna delimitacja wersowa jest nadal chętnie wykorzystywana przez poetów i pozostaje zjawiskiem żywotnym. Jako przykład posłużyć może utwór Justyny Radczyńskiej, którego pierwsza strofoida została przytoczona poniżej.

Dostałam dziś dowód miłości, a więc jednak ktoś mnie kocha. Mogę mieć tę pewność, że tak, i nieważne, kto mi go przysłał. Niech to pozostanie naszą tajemnicą, małym misterium. Bo przecież gdyby nawet to była, powiedzmy perfumeria - to miłość jest już dziś udowodniona ${ }^{13}$.

Niewielkie różnice w długości pierwszych trzech linijek i niewielka w oryginale przestrzeń po prawej stronie od nich, dochowanie wszelkich reguł ortograficznych i interpunkcyjnych, pełna przejrzystość złożonej organizacji składniowej wszystko to sprawia, że przywołany utwór trudno czytać wersami. Respektowanie silnych działów składniowych wewnątrz wersu musi prowadzić do zagłuszenia pauzy w wygłosie; osłabianie realizacji tych działów na rzecz końcowej pauzy wydaje się z kolei działaniem wbrew organizacji utworu.

${ }^{13}$ J. Radczyńska, Jaki korbowód zmienia muśnięcia w rotacje?, cyt. za: Warkoczami. Antologia nowej poezji, red. S. Głuszak, B. Gula, J. Mueller, Warszawa 2016, s. 118. 
Utwór Radczyńskiej sprawia wrażenie uporządkowanego graficznie. Został podzielony na nieprzypadkowe linijki, jest zatem „,autonomiczną organizacją przestrzenną, dwuwymiarową" 14 , która jednak nie oddaje żadnego systemowego porządku. O ile w cytowanej strofoidzie mówi się o pewności, o tyle delimitacja graficzna i wynikające $\mathrm{z}$ niej przerwy $\mathrm{w}$ toku wypowiedzi zdradzają wahanie i tym samym - pozorność ładu. Ekspozycja eliptycznych członów w klauzuli zmusza - jak opisał to Skibski - do wysuwania hipotez składniowych ${ }^{15}$, snucia naprędce domysłów. Tym samym czytający jak gdyby powtarza czynność tekstowego podmiotu, próbując w napięciu uzupełnić przerywany wahaniami ciąg myśli. Jednakże dla interpretacyjnych działań odbiorcy to nie wers czy linijka wydają się kluczowe, lecz jest nim owo napięcie pomiędzy ciągłością a fragmentarycznością utrzymujące się na przestrzeni całego tekstu.

\section{Wersy o niejasnych granicach}

Nie tylko intonacyjne i semantyczne scalenie wersów może być jednak kłopotliwe. Zdarza się, że również pod względem graficznym granice przedstawiają się niejednoznacznie. Tak bywa między innymi w utworach Barbary Klickiej:

Niech Twoje dziwki, kochany, będą dziwne jak kobiety po wyjściu z basenu, w chlorze i czepku. Niech mają ręce z ołowiu, niech mają z brązu. Niech kołysząc biodrami grzechoczą jak węże, jak wystraszone dziecięce zabawki ${ }^{16}$.

Utwór Kochany swoją graficzną organizacją upodabnia się do prozy i do stosowanego w niej podziału na akapity. Złożoność składniowa, respektowanie reguł ortograficznych i interpunkcyjnych, podobnie jak w wierszu Radczyńskiej, dodatkowo utrudniają lekturę wers po wersie. Na pierwszy plan wysuwa się zatem linearność. $Z$ drugiej jednak strony, cały tekst jest wyraźnie zorganizowany anaforycznie, z tym że w całostki dłuższe niż linijka. Całostki te są z kolei konsekwentnie zrytmizowane wewnętrznie przez liczne powtórzenia i paralelizmy składniowe, tak że dałyby się łatwo rozpisać na wersy w taki sposób, by każdy rozpoczynał się od „niech”. Utwór składałby się wtedy z dwu- lub trójwersowych strofoid, a całość nabrałaby litanijnego rytmu.

Zapewne nie o taki efekt jednak chodziło. Zastosowany zapis podkreśla ciągłość w ramach poszczególnych sekwencji i tym samym dynamizuje je, zacierając czytelność paralelizmów i burząc wewnętrzny rytm. Ciągi skojarzeń zawarte w poszczególnych sekwencjach dają przez to wrażenie gorączkowych erupcji myśli w kolejnych, obsesyjnych nawrotach. $\mathrm{Z}$ tego też względu akapity

\footnotetext{
${ }^{14} \mathrm{~W}$. Sadowski, Wiersz wolny jako tekst graficzny, s. 238.

${ }^{15}$ K. Skibski, op. cit., s. 41-45.

${ }^{16}$ B. Klicka, Kochany, cyt. za: Warkoczami, s. 121.
} 
w utworze Klickiej zdają się stanowić raczej kompozycyjny odpowiednik pojedynczego wersu niż trójwersowej strofoidy.

W nieco inny sposób zatarcie wyrazistości podziału wierszowego odbywa się w Afterparty. Apokalipsie Piotra Przybyły ${ }^{17}$. Wersy stanowią tu, co prawda, jednoznacznie wydzielone linijki, ale $\mathrm{w}$ większości utworów są one długie i często tylko subtelnie różnią się pomiędzy sobą rozpiętością. Są za to wyraźnie pogrupowane w kilkulinijkowe segmenty, niemal zawsze zakończone znakiem interpunkcyjnym (zazwyczaj średnikiem). Segmenty te najczęściej zaczynają się anaforycznie, od tej samej formy orzeczenia poprzedzonego spójnikiem „i” lub też od samego „i”, dzięki czemu każda całostka poematu sprawia wrażenie ogniwa konstrukcji polisyndetycznej:

i prezentuję królikom mój syntezator mowy: gajerek made in Gwadelupa o numerze ciemność z domieszką indygo. Ponoć kompatybilny z kosmosem, choć zawiesił się w województwie dolnośląskim - to jest w takiej czarnej plamce na hybrydowym piasku, gdzie zombie chcą puenty z furgonetką, a potem się dziwią;

i prezentuję swój niepokój, który układam w kant: ej, odbierasz go, bo pytam: po co komu porzeczki albo Roczniki Naukowe Polskiego Towarzystwa Zootechnicznego? Praczkom czy bawidamkom? Dodaj, czy podobnie jest ze stopami, gdy Częstochowa dopiero w głowie, a stygmaty już na asfalcie na odcinku Stara Rawa - Księża Wola? ${ }^{18}$

Podstawowym elementem kompozycyjnym wydają się tutaj właśnie owe segmenty, jawiące się jako odcinki większego ciągu, na kształt sekwencji rozbudowanych zdań czy myśli, przy czym ciąg ten wykracza poza pojedynczy utwór i obejmuje całość zbioru.

Efekt ten osiągnięty został dzięki dwóm zabiegom. Po pierwsze, Przybyła kończy każdy utwór kropką, ale rezygnuje z wielkiej litery na oznaczenie początku kolejnego. Po drugie, autor zrezygnował z zapisania tytułów nad poszczególnymi utworami, choć - jak sugeruje spis treści - każdy tekst jest jakoś zatytułowany. Zasygnalizowane kropką zakończenie okazuje się tym samym względne. Pominięcie tytułu przed kolejną całostką kompozycyjną oraz brak inicjalnej wielkiej litery i liczne paralelizmy sprawiają wrażenie powrotu do pozornie zakończonej już myśli czy też do - tego samego za każdym razem - punktu wyjścia. Każdy kilkulinijkowy segment jest pojedynczym krokiem w eksploracji świadomości, każdy utwór - innym etapem, pójściem „w innym kierunku”. Zawsze jest to jednak ten sam proces i ta sama świadomość.

\footnotetext{
${ }^{17}$ P. Przybyła, Apokalipsa; Afterparty, Łódź 2015.

${ }^{18}$ Idem, i prezentuję królikom mój syntezator mowy, w: idem, op. cit., s. 31
} 


\section{Przerwana ciągłość wersu}

Odwrotność dla kompozycyjnych odpowiedników wersu przekraczających długość jednej linijki stanowią pojedyncze linijki, które dają się interpretować jako dwa i więcej wersów.

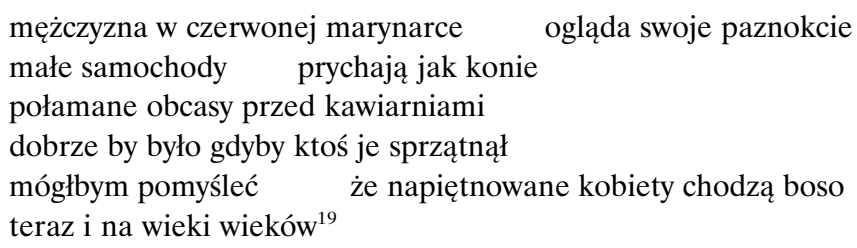

W wierszu Piotra Kępińskiego Jak gdyby przed chwila przetoczyła się tędy wojna pojawiają się wersy porozdzielane graficznie pustą przestrzenią na dwie części. W Wierszu wolnym jako tekście graficznym Witold Sadowski nazwał taki zabieg spacją ${ }^{20}$ i stwierdził, że przemierzany wzrokiem odstęp, separując człony składniowe, spowalnia proces scalania wersu, sugeruje przerwy w toku wypowiedzi, naśladujące wahanie, zdziwienie bądź namysł.

Możliwe wydaje się jednak również odczytanie z pominięciem spacji, na zasadzie skoku, analogicznego do odbywającego się pionowo, od wersu do wersu ${ }^{21}$. To z kolei pozwalałoby traktować omawiane linijki jako złożone $\mathrm{z}$ dwóch odrębnych wersów, z których każdemu przysługiwałaby taka porcja uwagi jak pojedynczej linijce. Lektura przebiegałaby w takim wypadku w sposób nietypowy, odtwarzając niejako błądzenie wzrokiem w poszukiwaniu kolejnego fragmentu (wersu), który nie znajduje się, zgodnie z przyzwyczajeniami, poniżej, lecz obok.

Spostrzeżenia te można odnieść również do utworów Białoszewskiego, np. do rozłamu $w$ barze mlecznym z niespodziewanem:

ja stoję w ogonku

on stoi ze mną ale na boku pali

ona ta za mną ogląda makaron po cenniku

druga na boku nie je nic tutejszego obiera

pomarańcze ${ }^{22}$

${ }^{19}$ P. Kępiński, Jak gdyby przed chwila przetoczyla się tędy wojna, cyt. za: Antologia nowej poezji polskiej 1990-1999, red. R. Honet, M. Czyżkowski, Kraków 2000, s. 126.

${ }^{20} \mathrm{~W}$. Sadowski, Wiersz wolny jako tekst graficzny, s. 114.

${ }^{21}$ Jedną ze wskazanych przez Sadowskiego konsekwencji ukształtowania tekstu w linijki jest wymuszenie innego toku lektury: tekst graficzny przemierza się właśnie krok po kroku, linijka po linijce; ibidem, s. 239.

${ }^{22}$ M. Białoszewski, Rozłam w barze mlecznym z niespodziewanem, w: idem, Utwory zebrane, t. 1, Warszawa 2016, s. 288. Utwór opublikowany pierwotnie w: idem, Mylne wzruszenia, Warszawa 1961. 
Przez Sadowskiego zabieg ten został zresztą opisany jako charakterystyczny dla tego poety. Badacz wskazuje, że takie graficzne rozdzielenie pojawia się w poezji Białoszewskiego „zwłaszcza wtedy, kiedy trzeba zmienić osobę lub przedmiot obserwacji albo wprowadzić określony dystans czasowy lub przestrzenny"23. Owa zmiana stanie się jeszcze wyraźniejsza, jeśli każdą taką (rzekomo pojedynczą) linijkę będziemy czytać i interpretować jako szereg (czyli poziomą serię) kilku wersów. W takim wypadku każda cząstka zyskuje bowiem ten sam stopień autonomii i może skupiać tyle samo uwagi, co każdy inny wers; pojęcie spacji zakłada, że cząstki te są jedynie składowymi wersu i jako takie nie mogą się w pełni usamodzielnić.

\section{Blok tekstu}

Na przykładzie utworów Klickiej i Przybyły omówione zostały zabiegi, które można odczytać jako wyodrębnienie odpowiadających wersom konstrukcji o długości przekraczającej jedną linijkę. Zjawisko rozciągania wersów można jednak zaobserwować także w znacznie radykalniejszej formie - kiedy tekst, o którym na jakiejś podstawie przypuszczamy, że został pomyślany jako wiersz, jawi się wizualnie jako zupełnie ciagły, pozbawiony jakichkolwiek uchwytnych na pierwszy rzut oka wyróżników wiersza wolnego.

Pan Sta... He... ukłonił się w drzwiach przejścia Nie

Wiadomo Co Za Panu który na przejście się odkłonił

Panu Sta... He... tak że Pan Sta... He... odkłonił się

Nie Wiadomo Co Za Panu w przejściu tak że Nie

Wiadomo Co Za Pan Panu Sta... He... aż się zwierzył

$\mathrm{z}$ uprzejmości z przejśćc ${ }^{4}$

Przytoczony powyżej utwór Białoszewskiego przy przedlekturowym oglądzie przypomina wyjustowaną prozę, ciągły tekst, którego kształt determinowany jest wyłącznie czynnikami zewnętrznymi i przypadkowymi (przyjęta dla strony szerokość marginesów, zadana interlinia). Ponieważ jednak utwór ten zamieszczony został w tomiku poetyckim i jest otoczony tekstami, które bez wahania uznać można za przykłady tekstów graficznych, to jego blokowe ukształtowanie staje się nacechowane i tym samym wzbudza pewną ostrożność.

Czytelnik może mimowolnie próbować odszukać w tekście autonomiczne linijki i czytać go wersami. Jest to jednak bardzo trudne, utwór bowiem wydaje się zorganizowany graficznie i składniowo tak, by dawać wrażenie jak największej

${ }^{23}$ W. Sadowski, Wiersz wolny jako tekst graficzny, s. 114.

${ }^{24}$ M. Białoszewski, Po niezapakowaniu paczki / u En-pisarki / z uprzejmości że jej pomoc domowa / ze on, w: idem, Utwory zebrane, t. 1, s. 207. Utwór opublikowany pierwotnie w: idem, Rachunek zachciankowy, Warszawa 1959. 
ciągłości. Występujące liczne powtórzenia i paralelizmy nie zostały wykorzystane na rzecz uwydatnienia czy w ogóle wyodrębnienia wersów. Wręcz odwrotnie: z powodu swojego bezładnego rozmieszczenia zdają się raczej odzwierciedlać chaotyczny przebieg opisanej sytuacji, odbijać dezorientację towarzyszącą uczestnikom tej pętli wydarzeń. Prozodia zapisu została tutaj zaangażowana do organizacji graficznej utworu, nie po to jednak, by go podzielić na linijki, lecz by nadać mu spotęgowaną ciągłość.

Podobny zabieg w niektórych swoich utworach wykorzystuje, maksymalizując jego efekt, Maria Cyranowicz. Dzieje się tak np. w Monologii:

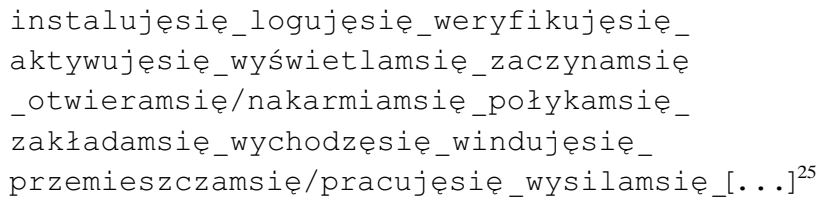

Zastąpienie spacji podkreślnikiem, łączna pisownia czasowników zwrotnych (również neologicznych) z zaimkiem się (np. „przejmujęsię”), ukośnik jako jedyny znak przestankowy - wszystko to jawi się jako wykorzystanie prozodii zapisu na rzecz zobrazowania nużącej, nieprzerwanej monotonii, przypominającej wykonywanie kodu przez program komputerowy.

Wskazane dotychczas zjawiska zdają się celowym zaburzeniem czytelnego podziału na wersy. Autorom nie chodzi zatem o wyrazisty porządek wierszowy, lecz właśnie o kształtowanie tekstu z jednostek (sekwencji) o rozmytych granicach, stawiających opór zautomatyzowanej lekturze, poprzedzonej jednoznacznym zaklasyfikowaniem tekstu do wiersza lub prozy. Tego typu utwory lub konstrukcje zdają się przywoływać obie kategorie jednocześnie i z równą siłą, stapiając je niejako w jednym tekście. Tym samym zwracają uwagę na pierwszy aspekt owego pogranicza - zatarcie granic pomiędzy wierszem wolnym a prozą.

\section{Mieszanie wiersza wolnego i prozy}

W sferze pogranicznej ulokować można jednak nie tylko teksty scalające w sobie wiersz wolny z prozą, lecz również takie utwory i zbiory utworów, w których pojawiają się fragmenty pisane raz wierszem wolnym, raz prozą. Tego typu połączenia mogą oczywiście nie nastręczać czytelnikowi ani badaczowi żadnych trudności. Wiersz wolny może bowiem występować w swojej dobrze uchwytnej odmianie, a fragmenty nim pisane mogą być wyraźnie oddzielone od części zapisanych prozą. Tak jest np. w Gdzie stońce wschodzi i kędy zapada Czesława Miłosza ${ }^{26}$, gdzie wierszowanym częściom poematu, odnoszącym się

\footnotetext{
${ }^{25}$ M. Cyranowicz, Monologia, cyt. za: Warkoczami, s. 255.

${ }^{26}$ C. Miłosz, Gdzie stońce wschodzi i kędy zapada, Gdańsk 2004.
} 
do przeszłości i miejsc odległych, towarzyszą zapisane prozą autokomentarze podmiotu osadzone w tekstowej teraźniejszości. Oprócz tego, że wiersz i proza zostały przez Miłosza wykorzystane zgodnie z ich walorami ekspresywno-stylistycznymi, pełnią też dodatkową funkcję: sygnalizują i oddzielają dwie płaszczyzny tekstowego świata. Dla tego typu współwystępowania wiersza wolnego i prozy zaproponować można nazwę przeplotu.

Jakkolwiek Gdzie stońce wschodzi... składa się z bardzo niejednorodnych fragmentów, to jednocześnie daje się ujmować całościowo jako poemat. Przeplot wiersza wolnego i prozy można jednak dostrzec także w kompozycjach złożonych z pojedynczych utworów (zbiorach poetyckich i antologiach), jak np. tomiki Białoszewskiego czy Epilog burzy ${ }^{27}$ Zbigniewa Herberta.

Umieszczenie obok siebie reprezentacji obu członów opozycji wiersza i prozy choć w pierwszej chwili może to eksponować wyraźną granicę pośrodku - na tle omawianej tu tendencji do zacierania wyrazistości delimitacji wierszowej zdaje się sugerować istnienie czegoś pomiędzy nimi, uzmysławia sam fakt dzielącego je obszaru i jak gdyby z obu kierunków do niego wprowadza. Kolejnym krokiem w stronę pogranicza byłoby współwystępowanie wyraźnie oddzielonych fragmentów wiersza wolnego i prozy w ramach jednego utworu, czyli bliższe ich sąsiedztwo ${ }^{28}$.

Jeden z możliwych wariantów takiego współwystępowania stanowi zastosowanie wiersza wolnego $\mathrm{w}$ tytule utworu prozatorskiego (lub odwrotnie: tytułu prozatorskiego w wierszu wolnym). Tak dzieje się np. w przywołanym wcześniej Po niezapakowaniu paczki / u En-pisarki / z uprzejmości że jej pomoc domowa / $\dot{z} e{ }^{2}{ }^{29}$ Białoszewskiego, gdzie tekst (na pierwszy rzut oka) typowo prozatorski opatrzony został tytułem podzielonym na wyraźne linijki. Sytuacja odwrotna zachodzi w wierszu Umiem żyć w biedzie... Justyny Bargielskiej.

Umiem żyć w biedzie, pochodzę z patologicznej rodziny, więc zmiana stylu życia $w$ zgodzie $z$ własnym sumieniem mnie nie przeraża

Dlaczego pani nie chce ratować tego dziecka?

Dlatego, bo to dziecko nie jest ratowalne.

Gdyby to dziecko było ratowalne,

dałabym mu pana imię na jego imię $[\ldots]^{30}$.

${ }^{27}$ Z. Herbert, Epilog burzy, Wrocław 1998.

${ }^{28}$ Takie właśnie połączenie występuje w poszczególnych partiach Gdzie słońce wschodzi $i$ kędy zapada. W takiej perspektywie omówione wcześniej zatarcie granic byłoby niejako krokiem finalnym, bodaj najpełniej wyzyskującym możliwości owego pogranicza.

${ }^{29}$ Utwór został zacytowany w całości wcześniej.

${ }^{30} \mathrm{~J}$. Bargielska, Umiem żyć w biedzie..., cyt. za: Warkoczami, s. 58. 
W obu ostatnio cytowanych utworach fragmenty reprezentujące wiersz wolny i prozę uwypuklają podział na tekst i paratekst. Nie jest to wszelako ich jedyna funkcja. Oba w swej części zasadniczej (czyli z wyłączeniem tytułu ${ }^{31}$ ) okazują się bowiem, wbrew przedlekturowej, graficznej sugestii, dość nietypowymi realizacjami prozy (u Białoszewskiego) i wiersza wolnego (u Bargielskiej). Nietypowa organizacja utworu Białoszewskiego polega na uporządkowaniu tekstu w blok. W utworze Bargielskiej z kolei wyrazistość delimitacji wierszowej jest zatarta przez delimitację składniową, potoczny język i stosunkowo niewielkie zróżnicowanie długości kolejnych linijek. W tych wypadkach osobliwy tytuł zdaje się więc sygnałem równie specyficznej organizacji tekstu głównego: w utworze Białoszewskiego sugeruje istnienie wierszowego porządku w bloku tekstu, u Bargielskiej niejako podważa zasadność graficznej organizacji wypowiedzi w linijki. Ten aspekt pogranicza wiersza wolnego i prozy, czyli ich współistnienie na różnych poziomach utworu, nazwać można nawarstwieniem ${ }^{32}$.

\section{Ekspozycja graficznego aspektu tekstu}

Wszystkie wskazane powyżej zjawiska (zatarcie granic, przeplot, sąsiedztwo oraz nawarstwienie wiersza i prozy) wiążą się ściśle z graficznym wymiarem tekstu i jako takie zdają się potwierdzać wagę wizualnego aspektu tekstu poetyckiego ${ }^{33}$. W związku z tym i zgodnie z przyjętym na wstępie założeniem można je uznać za przejawy ogólniejszej tendencji do eksponowania graficznej warstwy tekstu. Niezwykle istotna staje się w ten sposób prozodia zapisu, którą jednak na ich podstawie należałoby rozumieć szerzej niż Sadowski, traktując ją raczej jako chwyt, którego zastosowanie może przynosić różne rezultaty. Jednym z efektów graficznej organizacji tekstu może być oczywiście podział na linijki, nie jest to jednak jedyna możliwość. Omówione zabiegi sugerują nawet, że prozodia zapisu wykorzystywana jest albo do ekspresywnego wyzyskiwania fragmentaryzacji tekstu, albo do równie ekspresywnego pogłębiania jego ciągłości. Graficzne ukształtowanie wysuwa się bowiem na pierwszy plan nie tylko

${ }^{31}$ Oczywiście problem komplikują dodatkowo wskazana przez Gérarda Genetta „transtekstualna" relacja tekstu i paratekstu oraz hierarchia instancji nadawczych w utworze literackim, tak jak opisała ją Aleksandra Okopień-Sławińska; cf. G. Genette, Palimpsesty. Literatura drugiego stopnia, tłum. T. Stróżyński, A. Milecki, Gdańsk 2014; A. Okopień-Sławińska, Relacje osobowe w literackiej komunikacji, w: eadem, Semantyka wypowiedzi poetyckiej, Kraków 1998. Tutaj problematyka ta nie będzie szczegółowo rozważana, a utwór i jego tytuł są traktowane jako pewna (niejednorodna) całość.

${ }^{32}$ Zjawisko to zwraca uwagę na ogólniejsze zagadnienie: czy do obszaru wersologicznych badań należałoby włączać również parateksty? Zaproponowany tutaj opis nawarstwienia wiersza wolnego i prozy zakłada odpowiedź pozytywną. Sadowski.

${ }^{33} \mathrm{Na}$ aspekt ten zwrócili szczególną uwagę w cytowanych pracach Grabowski, a zwłaszcza 
w tekstach podzielonych na linijki, ale wszędzie tam, gdzie jawi się jako nietypowy, zwracający na siebie uwagę, chwyt. Zbiór tekstów wykorzystujących tę szerzej rozumianą prozodię zapisu i reprezentujących kategorię bardziej obszerną niż kategoria „wiersza wolnego jako tekstu graficznego” można określić mianem tekstów graficznie zorganizowanych.

Rozszerzenie funkcjonalności prozodii zapisu nie unieważnia pozostałych rozpoznań dokonanych przez Sadowskiego. Również w tekście graficznie zorganizowanym autonomię i samodzielne znaczenie uzyskiwać mogą rozmaite elementy wizualne, spośród których przywołany badacz wymienia np. kursywę, krój pisma, wielkość liter. Omówione powyżej utwory potwierdzają to spostrzeżenie, ale jednocześnie rozbudowują zaproponowany w Wierszu wolnym jako tekście graficznym katalog zabiegów wizualnych.

\section{Podsumowanie}

Przedstawione sposoby kwestionowania i przekraczania znanych i opracowanych teoretycznie konwencji wierszowych pozostają zjawiskiem istotnym i trudnym do przeoczenia. Stanowi to niebagatelny problem dla wersologii i zmusza do weryfikacji ugruntowanych $w$ niej koncepcji teoretycznych. Jednocześnie sam fakt podważania konwencji wierszowych jest zawsze formą ich jednoczesnego przywołania, dlatego mimo wszystko to właśnie wersologia wydaje się dziedziną najlepiej przygotowaną do opisu poetyki utworów zaliczonych tutaj do pogranicza.

Jak widać w przywołanych przykładach, niektórzy poeci nie dążą do klarownego podziału na wersy, lecz przeciwnie - starają się go podważyć i rozmyć. W przypadku takich tekstów przydatne może zatem okazać się spojrzenie z poziomu metawersologicznego. W ten sposób przedmiotem refleksji mógłby się stać nie mechanizm delimitacji wierszowej (skoro nie daje się go odnaleźć), lecz sposoby przywoływania i kwestionowania konwencji wierszotwórczych. Nie wiersz jako tekst byłby przedmiotem opisu, lecz wiersz jako pewna kategoria pojęciowa, niemająca egzemplifikacji bezpośrednio w utworze, ale przezeń zakładana i aktywizowana w czasie lektury. Zadaniem wersologa byłoby wtedy odkrycie i opisanie mechanizmów (składniowych, graficznych, intertekstualnych, ale także rytmicznych - graficzna organizacja tekstu nie eliminuje bowiem z niego rytmu), mogących skutecznie ją przywołać.

W tej perspektywie pogranicze wiersza i prozy ująć można nie tylko jako zbiór tekstów o niejednoznacznym statusie, ale też jako swoisty „ekoton”, oferujący środki ekspresji wyjątkowe i dostępne jedynie na tym obszarze. Prozodia zapisu pozwala tworzyć utwory graficznie zorganizowane, oscylujące pomiędzy szczególnie silnie ugruntowanymi kulturowo graficznymi formami wiersza i prozy, tak aby powstała kompozycja graficzna uzyskała specyficzne nacechowanie ekspresywne. 
Omówiona w artykule graficzna organizacja tekstu polegać może nie tylko na jego fragmentaryzacji, ale też na wzmożeniu ciągłości. Nienacechowany graficznie tekst nie jest bowiem maksymalnie ciągły. Proza, zwłaszcza nieliteracka, wykorzystuje podział na wyrazy graficzne, akapity i strony, respektuje reguły interpunkcji i ortografii, wymaga też ruchu gałek ocznych w pionie, $\mathrm{z}$ wiersza (w znaczeniu typograficznym) do wiersza. Prozodię zapisu można zatem wyzyskać także do ukształtowania tekstu nacechowanego nie poprzez fragmentaryzację, ale poprzez spotęgowaną ciągłość. To z kolei znacząco poszerza obszar badawczy wersologii, która od tej pory stawałaby się dziedziną zajmującą się wszelkimi tekstami graficznie zorganizowanymi.

\section{Bibliografia}

Bargielska, Justyna, Umiem żyć w biedzie, pochodzę z patologicznej rodziny, / więc zmiana stylu życia $w$ zgodzie $z$ wtasnym sumieniem mnie / nie przeraża, w: Warkoczami: antologia nowej poezji, red. S. Głuszak, B. Gula, J. Mueller, Warszawa 2016.

Białoszewski, Miron, Utwory zebrane, t. 1, Warszawa 2016.

Borowy, Wacław, Rytmika prozy Żeromskiego, w: O Żeromskim. Rozprawy i szkice, wyd. 2, Warszawa 1964.

Cyranowicz, Maria, Monologia, w: Warkoczami: antologia nowej poezji, red. S. Głuszak, B. Gula, J. Mueller, Warszawa 2016.

Dłuska, Maria, Drugi szkic o pograniczu prozy $i$ wiersza, w: Prace wybrane, t. 3, red. S. Balbus, Kraków 2001.

Dłuska, Maria, Między proza a wierszem, w: Prace wybrane, t. 3, red. S. Balbus, Kraków 2001.

Dłuska, Maria, Modernistyczny barok Żeromskiego. Studium prozy poetyckiej pisarza, w: Prace wybrane, t. 3, red. S. Balbus, Kraków 2001.

Dłuska, Maria, Studia z historii i teorii wersyfikacji polskiej, t. 2, Warszawa 1978.

Genette, Gérard, Palimpsesty. Literatura drugiego stopnia, thum. T. Stróżyński, A. Milecki, Gdańsk 2014.

Grabowski, Artur, Wiersz, forma i sens, Kraków 1999.

Herbert, Zbigniew, Epilog burzy, Wrocław 1998.

Kępiński, Piotr, Jak gdyby przed chwila przetoczyła się tędy wojna, w: Antologia nowej poezji polskiej 1990-1999, red. R. Honet, M. Czyżkowski, Kraków 2000.

Klicka, Barbara, Kochany, w: Warkoczami: antologia nowej poezji, Warszawa 2016.

Kulawik, Adam, Wersologia. Studium wiersza, metru i kompozycji wersyfikacyjnej, Kraków 1999.

Mayenowa, Maria Renata, Poetyka teoretyczna, wyd. 3, Wrocław et al. 2000.

Miłosz, Czesław, Gdzie słońce wschodzi i kędy zapada, Kraków 2004.

Okopień-Sławińska, Aleksandra, Relacje osobowe w literackiej komunikacji, w: Semantyka wypowiedzi poetyckiej, Kraków 2001.

Przybyła, Piotr, Apokalipsa. Afterparty, Łódź 2015. 
Radczyńska, Justyna, Jaki korbowód zmienia muśnięcia w rotacje?, w: Warkoczami: antologia nowej poezji, red. S. Głuszak, B. Gula, J. Mueller, Warszawa 2016.

Sadowski, Witold, Europejski wiersz litanijny. W innej czasoprzestrzeni, Warszawa 2018. Sadowski, Witold, Litania i poezja, Warszawa 2018.

Sadowski, Witold, Wiersz wolny jako tekst graficzny, Kraków 2004.

Skibski, Krzysztof, Poezja jako iteratura, Poznań 2017.

Urbańska, Dorota, Wiersz wolny. Próba charakterystyki systemowej, Warszawa 1995.

WoJCIECH Pietras - mgr, doktorant w Zakładzie Poetyki, Teorii Literatury i Metodologii Badań Literackich Instytutu Literatury Polskiej UW. Główne zainteresowania badawcze: wersologia, w szczególności teoria wiersza wolnego i obszar pograniczny pomiędzy wierszem i prozą, oraz kultura internetu. 